\title{
Highly proteolytic bacteria from semi- ripened Chiapas cheese elicit angiotensin- I converting enzyme inhibition and antioxidant activity
}

Article

Accepted Version

Creative Commons: Attribution-Noncommercial-No Derivative Works 4.0

Gonzalez-Gonzalez, C. R., Machado, J., Correia, S., McCartney, A. L., Elmore, J. S. and Jauregi, P. (2019) Highly proteolytic bacteria from semi-ripened Chiapas cheese elicit angiotensin-I converting enzyme inhibition and antioxidant activity. LWT-Food Science and Technology, 111. pp. 449-456. ISSN 0023-6438 doi: https://doi.org/10.1016/j.lwt.2019.05.039 Available at https://centaur.reading.ac.uk/83763/

It is advisable to refer to the publisher's version if you intend to cite from the work. See Guidance on citing.

To link to this article DOI: http://dx.doi.org/10.1016/j.Iwt.2019.05.039

Publisher: Elsevier

All outputs in CentAUR are protected by Intellectual Property Rights law, including copyright law. Copyright and IPR is retained by the creators or other copyright holders. Terms and conditions for use of this material are defined in the End User Agreement. 


\section{www.reading.ac.uk/centaur}

\section{CentAUR}

Central Archive at the University of Reading

Reading's research outputs online 


\section{Highly proteolytic bacteria from semi- ripened Chiapas cheese elicit angiotensin- I converting enzyme inhibition and antioxidant activity}

Article

Accepted Version

Gonzalez-Gonzalez, C. R., Machado, J., Correia, S., McCartney, A. L., Elmore, J. S. and Jauregi, P. (2019) Highly proteolytic bacteria from semi-ripened Chiapas cheese elicit angiotensin-I converting enzyme inhibition and antioxidant activity. LWT-Food Science and Technology, 111. pp. 449-456. ISSN 0023-6438 doi: https://doi.org/10.1016/j.Iwt.2019.05.039 Available at http://centaur.reading.ac.uk/83763/

It is advisable to refer to the publisher's version if you intend to cite from the work. See Guidance on citing.

To link to this article DOI: http://dx.doi.org/10.1016/j.Iwt.2019.05.039

Publisher: Elsevier

All outputs in CentAUR are protected by Intellectual Property Rights law, including copyright law. Copyright and IPR is retained by the creators or other copyright holders. Terms and conditions for use of this material are defined in the End User Agreement. 
www.reading.ac.uk/centaur

\section{CentAUR}

Central Archive at the University of Reading

Reading's research outputs online 


\section{Highlights}

- Mexican Chiapas cheese shows high proteolytic activity by native bacteria.

- Chiapas cheese showed up to $0.78 \mathrm{~g} / \mathrm{kg}$ of antihypertensive GABA content.

- Chiapas cheese elicit angiotensin-I converting enzyme inhibition.

- Fermented milk of selected isolates induced ACE inhibitory \& antioxidant activities. 


\section{Highly proteolytic bacteria from semi-ripened Chiapas cheese elicit}

\section{2 angiotensin-I converting enzyme inhibition and antioxidant activity}

3 Cid R. Gonzalez-Gonzalez ${ }^{\mathrm{a} *}$, Joana Machado $^{\mathrm{b}}$, Sandra Correia ${ }^{\mathrm{b}}$, Anne L. McCartney ${ }^{\mathrm{c}}, \mathrm{J}_{\text {. Stephen Elmore }}^{\mathrm{c}}$,

$4 \quad$ Paula Jauregi ${ }^{\mathrm{c}}$

5 a Instituto Superior Tecnológico de Acayucan, Costera del Golfo Km 216.4, Acayucan, Veracruz, Mexico, 96100

6 b Universidade Católica Portuguesa, Rua de Diogo Botelho, 1327, Porto, Portugal, 4169-005

$7 \quad{ }^{\mathrm{c}}$ University of Reading, Whiteknights, Reading, United Kingdom, RG6 6AH

$8 *$ Corresponding author: cidgonzalez@itsacayucan.edu.mx

\section{Abstract $^{1}$}

Chiapas cream cheese $(\mathrm{CCH})$ manufacturing process involves a long acid-enzymatic coagulation period of full-fat cow raw milk to achieve an acid and crumbly cheese. These sensorial aspects are related to lactic acid bacteria activity during ripening. Our main objective was to test the hypothesis that $\mathrm{CCH}$ contained highly proteolytic strains able to release bioactive compounds upon milk-protein hydrolysis.

First, the proteolysis of $\mathrm{CCH}$ was evaluated considering the peptide and amino acid profiles of cheese samples collected from Veracruz (AVCH) and Tabasco (HTCH). The angiotensin-converting-enzyme (ACE) inhibitory activity in cheese water-soluble fractions was evaluated. Thereafter, strains from both $\mathrm{CCH}$ samples were isolated and selected based on their proteolytic capability, genetic fingerprint differentiation and growth conditions. Finally, a range of activities in vitro were tested in milk fractions

\footnotetext{
${ }^{1}$ ABBREVIATIONS:

2,2'-azinobis(3-ethylbenzothiazoline-6-sulfonic acid) diammonium salt $\left(\mathrm{ABTS}^{+\bullet}\right)$; Acayucan Veracruz Chiapas Cheese (AVCH); angiotensin-I converting enzyme (ACE); ACE-inhibitory activity (ACEi); ACE-inhibitory efficiency ratio (IER); antioxidant activity (AO); antioxidant activity/total protein efficiency ratio (AOER); Bifidobacterium (B.); brain heart infusion (BHI); Chiapas cream cheese $(\mathrm{CCH})$; Degree of hydrolysis (DH\%); free amino acids (FAA); N-[3-(2-furyl)acryloyl]-Phe-Gly-Gly (FAPGG); fermented milk soluble fractions (FMSF); ferric reducing antioxidant power (FRAP); $\gamma$ aminobutyric acid (GABA); Huimanguillo Tabasco Chiapas Cheese (HTCH); Lactobacillus (Lb.); lactic acid bacteria (LAB); phosphate buffered saline (PBS); Man Rogosa Sharpe (MRS); ophthaldialdehyde (OPA); reconstituted skim milk (RSM); reversed-phase high performance liquid chromatography (RP-HPLC); trolox equivalent (TE); trolox equivalent antioxidant capacity (TEAC); water soluble fractions (WSF).
} 


\section{Keywords:}

fermented with selected strains. $\mathrm{CCH}$ showed ACE inhibitory activity: $\mathrm{IC}_{50}=1.75-2.75 \mathrm{mg} / \mathrm{mL}$. Interestingly, AVCH contains $0.78 \mathrm{~g} / \mathrm{kg}$ of the antihypertensive $\gamma$-aminobutyric acid. Three highly proteolytic strains showed ACE and high antioxidant activities upon milk fermentation. In conclusion, $\mathrm{CCH}$ contain proteolytic strains able to release bioactive compounds from milk proteins and potentially useful to produce functional ingredients and foods.

Chiapas cheese; proteolysis; GABA; ACE-inhibitory activity; antioxidant

\section{Introduction}

Chiapas cream cheese $(\mathrm{CCH})$ is a semi-ripened traditional cheese manufactured in the tropical south of Mexico. It is characterised by its acidic taste and creamy sensory properties (i.e. mouth feel). These characteristics are conferred during the process that involves 3-5 h of whole raw milk maturation followed by $2-8 \mathrm{~h}$ of coagulation and acidification by endogenous lactic acid bacteria (LAB) at tropical conditions $\left(>25^{\circ} \mathrm{C}\right)$ (González-Córdova et al., 2016). CCH was reported a humidity of 48\%, a pH about 4.0, and 5\% of $\mathrm{NaCl}$ (Morales, Morales, Hernández, \& Hernández-Sánchez, 2011). LAB are able to release bioactive compounds from milk proteins by proteolysis during cheese ripening. For instance, Lactobacillus (Lb.) helveticus DSM13137, a proteolytic cheese starter, releases the antihypertensive peptides Ile-Pro-Pro and Val-Pro-Pro during milk fermentation (Seppo, Jauhiainen, Poussa, \& Korpela, 2003). The ACE inhibitory activity (ACEi) has been attributed as one of the main antihypertensive mechanisms of bioactive peptides. ACEi was reported in ripened Red Cheddar and Camembert with an $\mathrm{IC}_{50}$, the amount of protein to inhibit the ACE activity by $50 \%$, as low as $0.16 \mathrm{mg} / \mathrm{mL}$, whereas non activity was detected in cottage, an unripen cheese (Okamoto et al., 1995). Furthermore, Gupta, Mann, Kumar \& Sangwan (2013) showed a clear relationship between degree of hydrolysis (DH) and an increase of ACEi in cheese water-soluble fraction (WSF) when adding adjunct cultures at different stages of ripening Cheddar cheeses. Also, a positive correlation between ripening and the radical scavenging capability of Cheddar WSF was found when adding Lb. casei ssp casei 300 as adjunct culture (Gupta, Mann, Kumar, \& Sangwan, 2009). Indeed, it was reported that CCH possess higher 
antioxidant activity (AO) than other Mexican cheeses when assessed by the oxygen radical absorbance capacity (ORAC) method, suggesting that greater proteolytic activity in $\mathrm{CCH}$ compared to other cheese released more antioxidant compounds (Santiago-López et al., 2018). LAB strains with potential proteolytic activity have been reported in $\mathrm{CCH}$ (Morales et al., 2011). Also, CCH halotolerant strains Lb. plantarum, Lb. pentosus, and Lb. acidipiscis have shown probiotic characteristics such as antimicrobial activity and adhesion to mucin (Melgar-Lalanne, Rivera-Espinoza, Reyes Méndez, \& Hernández-Sánchez, 2013). Nonetheless, no studies have been published on the proteolytic activity of the microbiota contained in $\mathrm{CCH}$ and their ability to releasing bioactive compounds. Thus, the main objective of this study was to investigate a range of potential functionalities, i.e. antihypertensive, and /or antioxidant activities, associated to the proteolytic activity of the microbiota present in $\mathrm{CCH}$. Our first approach was to study the proteolysis occurred in $\mathrm{CCH}$ from two different regions considering the peptide and amino acid profile. Also, ACEi of cheese WSF was assessed. Subsequently, isolated strains from $\mathrm{CCH}$ samples were selected based on their proteolytic activity, ability to produce diacetyl and no catalase production and genetical fingerprint differentiation by using RAPD-PCR technique. ACEi and antioxidant activities were investigated in whey fermented with selected strains, which could potentially be used in the formulation and production of functional foods.

\section{Material and methods}

\subsection{Reagents and cheese sample preparation and characterisation}

Unless otherwise stated chemicals and reagents were obtained from Sigma-Aldrich, UK. Cheese samples labelled as "Queso Chiapas doble crema” were purchased from Mexican local markets at Acayucan Veracruz (AVCH) and Huimanguillo Tabasco (HTCH) from recent manufacture (1 week, according to the date of production labelled on the package) and stored at $5{ }^{\circ} \mathrm{C}$. Samples for microbial isolation and bioactivity assessment were diluted in phosphate buffered saline (PBS); $(0.01 \mathrm{M}$ phosphate buffered saline $(\mathrm{NaCl} 0.138 \mathrm{M} ; \mathrm{KCl}-0.0027 \mathrm{M}) ; \mathrm{pH} 7.4$, at $\left.25^{\circ} \mathrm{C}, 10 \% \mathrm{w} / \mathrm{v}\right)$. For amino acid analysis, samples were diluted in $0.1 \mathrm{~N} \mathrm{HCl}(10 \%$, w/v) and vortexed until complete dissolution. Diluted samples to be assessed for bioactivity were stored at $-20^{\circ} \mathrm{C}$. For $\mathrm{pH}$ determination $1 \mathrm{~g}$ of cheese was 

Instruments $\mathrm{pH} 211$.

\subsection{Determination of total protein, degree of hydrolysis and peptide profile}

The total amount of proteins (TP) was determined using bicinchoninic acid as described by GonzalezGonzalez, Tuohy \& Jauregi (2011). The degree of hydrolysis (DH\%) was determined using the method of o-phthaldialdehyde (OPA) described by Nielsen, Petersen \& Dambmann (2001) and modified by Gonzalez-Gonzalez et al. (2011). The peptide profile was determined by reversed-phase high performance liquid chromatography (RP-HPLC) using a gradient as described by Gonzalez-Gonzalez, Gibson \& Jauregi (2013).

\subsection{Amino acid profile of cheese samples}

The free amino acid (FAA) profiles of cheese samples, including $\gamma$-aminobutyric acid (GABA), were examined using a derivatisation assay kit EZ-Faast (Phenomenex USA), and running on a GC- Agilent 6890 GC-5975-MS system (Agilent, USA) in electron impact mode. The method used is based on Elmore, Koutsidis, Dodson, Mottram, \& Wedzicha (2005). The results were compared to those found in raw milk.

\subsection{Isolation of bacteria}

Bacterial isolation was carried out under both aerobic and anaerobic conditions at $37{ }^{\circ} \mathrm{C}$ by spreadplating ten-fold serial dilutions (prepared in half-strength peptone water) on appropriate agar plates; de Man Rogosa Sharpe (MRS) agar for aerobic cultivation and both MRS agar and Columbia blood agar for anaerobic cultivation (Oxoid Ltd., UK). One of each different colony morphotype from each plate was subcultured, together with randomly selected colonies to obtain an equal number of isolates from each plate (cheese, agar type and cultivation conditions). Colonies were subcultured on the same agar type and incubated for $48 \mathrm{~h}$ appropriately (aerobic/anaerobic) to obtain pure cultures. Purified isolates were then stored on cryogenic Microbank ${ }^{\mathrm{TM}}$ beads (ProLab Diagnostics, UK) at $-80^{\circ} \mathrm{C}$.

\subsection{Genetic fingerprinting of bacterial isolates}


DNA was extracted from each isolate using the phenol/chloroform method and randomly amplified polymorphic DNA-PCR (RAPD-PCR) employed to estimate the genetic variations of the isolates. The reaction mixture $(25 \mu \mathrm{L})$ comprised $5 \mu \mathrm{L}$ of $5 \mathrm{x}$ GoTaq Flexi buffer (Promega, UK), $2.5 \mu \mathrm{L}$ of dNTPs (0.4 mmol/L of each of dATP, dCTP, dGTP, dTTP; Promega), $1.5 \mu \mathrm{L}$ of $\mathrm{MgCl}_{2}$ (25 mmol/L; Promega), $1 \mu \mathrm{L}$ of primer OPA-09 (5'-GGGTAACGCC-3'; 20 pmol/mL; Sigma Genosys, UK), $1 \mu \mathrm{L}$ of GoTaq DNA polymerase (1.5 U/ $\mu \mathrm{L}$; Promega), $1 \mu \mathrm{L}$ of template DNA $(5 \mathrm{ng} / \mu \mathrm{L})$ and $13 \mu \mathrm{L}$ of sterile water. PCR was performed using Prime thermal cycler (with heated lid, $100^{\circ} \mathrm{C}$; Techne) programmed for 40 cycles of denaturation $\left(30 \mathrm{sec}\right.$ at $\left.94^{\circ} \mathrm{C}\right)$, annealing $\left(60 \mathrm{sec}\right.$ at $\left.38^{\circ} \mathrm{C}\right)$ and extension $\left(2 \mathrm{~min}\right.$ at $\left.72{ }^{\circ} \mathrm{C}\right)$, with a final 10 min extension step $\left(72^{\circ} \mathrm{C}\right)$. The reaction products were separated via agarose gel electrophoresis ( $1.5 \%$ in $1 \mathrm{x}$ TAE buffer [Fisher, UK] containing ethidium bromide $[0.5 \mathrm{ng} / \mathrm{mL}])$, using $1 \mathrm{~Kb}$ DNA ladder (Promega) as a molecular size indicator. DNA fragment patterns were visualized under UV light (Genesnap, Syngene) and analysed by Gel Compar II software.

\subsection{Fermentation of milk by isolated strains, diacetyl and catalase test}

Bacterial strains were reactivated on appropriate agar plates (aerobically/anaerobically), checked for purity (single colony type) and overnight brain heart infusion (BHI) broth cultures prepared (aerobically or anaerobically, as per original isolation). Milk fermentations were carried out in Hungate tubes with $15 \mathrm{~mL}$ of $10 \%(\mathrm{w} / \mathrm{v})$ reconstituted skim milk (RSM) using $1 \%$ inoculum of fresh overnight broth culture for each isolate (affording initial number of $10^{6}-10^{7}$ cells $/ \mathrm{mL}$ ). A negative control, using uninoculated BHI (1\%) was also included. The fermentations were incubated at $30{ }^{\circ} \mathrm{C}$ with continuous agitation for $24 \mathrm{~h}$. Samples of $2 \mathrm{~mL}$ were then taken and heated to $72{ }^{\circ} \mathrm{C}$ for $1 \mathrm{~min}$ to stop the enzymatic proteolysis and then centrifuged at $12,000 \mathrm{~g}$ for $10 \mathrm{~min}$. The supernatant was filtered and stored at $-20{ }^{\circ} \mathrm{C}$ until further analysis.

The catalase test was performed by mixing a colony into a drop of $3 \%$ hydrogen peroxide. Diacetyl production was determined to the supernatant fermented whey fraction according to King (1948). A purple ring at the top of the solution indicated the presence of diacetyl.

\subsection{Activity in vitro assays}


Assays for ACEi was performed in cheese samples. Furthermore, the ACEi and antioxidant activities were performed on fermented milk soluble fractions (FMSF) of selected strains according to criteria discussed below in section 3.3.

\section{ACE inhibitory activity}

The ACEi of cheese samples was determined using N-[3-(2-furyl)acryloyl]-Phe-Gly-Gly (FAPGG) according to the method described by Henda et al. (2013) with some modifications. Briefly, in a microplate well $10 \mu \mathrm{L}$ of ACE (250 mU solution with $0.05 \mathrm{M}$ Tris, $0.3 \mathrm{M} \mathrm{NaCl}$ in $50 \%$ glycerol solution, with the $\mathrm{pH}$ adjusted to 7.5 with $5 \mathrm{M} \mathrm{HCl}$ ) was mixed with $150 \mu \mathrm{L}$ of $0.88 \mathrm{mmol} / \mathrm{L}$ FAPGG in $0.05 \mathrm{M}$ Tris, $0.3 \mathrm{M} \mathrm{NaCl}$ and $10 \mu \mathrm{L}$ of test sample (diluted cheese or fermented milk fraction). $0.05 \mathrm{M}$ Tris, $0.3 \mathrm{M} \mathrm{NaCl}$ buffer was used as negative control and $5 \mathrm{M} \mathrm{HCl}$ was used as positive control (standard inhibition). The reaction kinetics was followed in a Tecan Microplate Reader - A-5082 Spectra FLUOR plus (Austria) for 30 minutes to obtain the slope inhibitor [FAPGG] vs time (min). The ACEi $\%$ was calculated in relation to the slope generated when no inhibitor was present in the reaction (slope blank) according to equation 1 (below).

Equation $1 \quad$ ACEi\% $=[1-($ slope inhibitor/slope blank $)] \times 100$

The $\mathrm{IC}_{50}$, defined as the concentration of protein needed to inhibit the activity of the enzyme by half, was calculated as the concentration needed to reduce the slope by $50 \%$ in relation to the slope blank. The ACEi\% in fermented milk fractions with selected strains, as described above, was determined according to the HPLC method described by Gonzalez-Gonzalez et al. (2011) using Hip-His-Leu as substrate.

\section{Antioxidant activity de FRAP}

The ferric reducing antioxidant power (FRAP) assay, based on the reduction of $\mathrm{Fe}$ (III) to $\mathrm{Fe}$ (II) by the action of antioxidants present, was performed according to Benzie \& Strain (1996). Serial dilutions of ascorbic acid were used as standards. 
150

For the trolox equivalent antioxidant capacity (TEAC) assay a solution of 2,2'-azinobis(3ethylbenzothiazoline-6-sulfonic acid) diammonium salt $\left(\mathrm{ABTS}^{+\bullet}\right)$ radical was prepared according to the method described by Guo \& Jauregi (2018). Triplicates of each reaction were read at $734 \mathrm{~nm}$ in a spectrophotometer Amersham Ultrospec 1100 Pro UV/Vis (Uppsala, Sweden). Trolox standards were used for quantification and data was expressed as $\mu$ mol trolox equivalent (TE). The antioxidant activity (AA\%) was calculated by using equation 2 (below).

Equation $2 \quad A A \%=1-\frac{A B S_{\text {sample }}}{A B S_{\text {control }}} \times 100$

Where $\mathrm{ABS}_{\text {control }}$ is the absorbance of $\mathrm{ABTS}^{+\bullet}$ in $\mathrm{PBS}$ and $\mathrm{ABS}_{\text {sample }}$ is the reaction absorbance with the sample.

\subsection{Data analysis and statistics}

All data analysis including one-way analysis of variance and Tukey post-hoc test were performed for comparative analysis among means for each bioactivity using R v.3.4.3. (R-Core-Team, 2017).

\section{Results and Discussion}

\subsection{Proteolysis in Chiapas cheese}

The proteolytic activity undergoing in $\mathrm{CCH}$ samples is depicted in the peptide profile chromatograms. Fig. 1 showed intact milk proteins in RSM as control (Fig. 1A), and a significant breakdown in AVCH (Fig. 1B) and $\mathrm{HTCH}$ (Fig. 1C) peptides profiles. Larger peak areas of peptides in AVCH suggests higher proteolytic activity than in $\mathrm{HTCH}$. This is confirmed by the FAA profiles, which show higher concentrations of total FAA in AVCH $(3.89 \mathrm{~g} / \mathrm{kg})$ than in $\mathrm{HTCH}(0.37 \mathrm{~g} / \mathrm{kg})$ (Table 2). These concentrations are similar to those found in Spanish cheese $(0.19$ and $69 \mathrm{~g} / \mathrm{kg}$ ) (Diana, Rafecas, Arco, \& Quílez, 2014). Moreover, the essential amino acids (AA) leucine, phenylalanine, lysine and valine were found in important amounts as FAA in AVCH and much higher than in $\mathrm{HTCH}$. Additionally, Ornithine 
175

176

177

178

179

180

181

182

183

184

185

186

187

188

189

190

191

192

193

194

195

196

197

198

199

200

201

(Orn), a non-proteinogenic AA found in certain types of ripened and semi-ripened cheeses, was found in AVCH samples $(0.18 \mathrm{~g} / \mathrm{kg})$ but not in $\mathrm{HTCH}$ samples. These differences on the peptide and FAA profiles may be explained by the activity of the microbiota of each sample as well as the differences in the manufacturing process (Santiago-López et al., 2018). Also, other factors such as salt content, pH and temperature storage may influence the release of FAA (Diana et al., 2014).

GABA is an important antihypertensive AA produced by LAB by the decarboxylation of glutamate. In this study, GABA was $0.78 \mathrm{~g} / \mathrm{kg}$ in AVCH (Table 2), being one of the highest GABA concentrations reported in cheese made of bovine milk so far; it has been found in Gouda $(0.177 \mathrm{~g} / \mathrm{kg})$, Cheddar $(0.048$ $\mathrm{g} / \mathrm{kg}$ ) and blue cheese (0.007 g/kg) (Nomura, Kimoto, Someya, Furukawa, \& Suzuki, 1998). Diana et al., (2014) reported GABA in Spanish cheeses in amounts ranging from 0.01 to $0.31 \mathrm{~g} / \mathrm{kg}$ in cheese made of cow's milk and 0.07 to $0.98 \mathrm{~g} / \mathrm{kg}$ in cheese made of ewe's milk. Nejati et al. (2013) reported a fermented milk using a selected $L b$. plantarum PU11 yielding up to $0.14 \mathrm{~g} / \mathrm{kg}$ GABA after $120 \mathrm{~h}$ of fermentation. Also, Lacroix, St. Gelais, Champagne, \& Vuillemard (2013) identified cheese starters Lactococcus lactis with high GABA production yielding up to $3.4 \mathrm{~g} / \mathrm{kg}$ of GABA in Danish Havarti cheese with added culture, attributing this to an extensive ripening and proteolysis. Also, glutamic acid was found in raw milk, yet it was not detected in cheese suggesting that it has been converted to GABA by LAB. Moreover, a reduction in blood pressure in mild-hypertensive patients was achieved following a 12-weeks intake of fermented milk with 0.010-0.012 g of GABA per day (Inoue et al., 2003). This content of GABA would be equivalent to daily consumption of approximately $13 \mathrm{~g}$ of AVCH.

\subsection{ACE inhibitory activity in vitro in cheese samples}

ACE inhibitory peptides may be released during cheese ripening. Although AVCH showed lower ACE inhibitory potency (i.e. higher $\mathrm{IC}_{50}$ value), no significant differences were found in ACEi between the two cheese samples (Table 1). The ACEi has been investigated in the norwegian traditional cheese Gamalost reporting $\mathrm{IC}_{50}$ values as low as $0.34 \pm 0.07 \mathrm{mg} / \mathrm{mL}$ after 10 days of ripening with native microbiota (Qureshi, Vegarud, Abrahamsen, \& Skeie, 2012). In a cheddar cheese enriched with $L b$. 
202

203

204

205

206

207

208

209

210

211

212

213

214

215

216

217

218

219

220

221

222

223

224

225

226

227

casei subps casei $\mathrm{IC}_{50}$ values were as low as $0.160 \pm 0.002$ after 3 months of ripening (Ong, Henriksson, $\&$ Shah, 2007). They observed that ACEi potency declines in cheese after a long period of ripening due to further proteolysis of bioactives peptides into their constituent AAs. This may explain why AVCH with higher proteolytic activity showed lower ACEi potency than HTCH samples.

\subsection{Isolation and selection of highly proteolytic strains}

Our research aim was to screen highly proteolytic native bacteria in $\mathrm{CCH}$ that were able to release bioactive compounds. A total of 89 bacterial strains were isolated (anaerobically and aerobically) but only 84 isolates were able to be subcultured and characterised. RAPD-PCR was performed to obtain a simple genetic fingerprint for each isolate and thus identify genetic variation across the strains (Fig. 2). The 84 isolates were also tested for catalase activity, diacetyl production and the final $\mathrm{pH}$ of fermented RSM during pre-screening (Table 3). A single representative for each biotype (based on fingerprint and similarities in the pre-screening characteristics: catalase negative isolates that were capable of producing diacetyl were considered desirable) was used in subsequent analyses. A pH $<4.7$ after $24 \mathrm{~h}$ of fermentation is also desirable, as it may be indicative of lactic acid production. The $\mathrm{pH}$ of control RSM was $6.50 \pm 0.03$. Eight isolates from $\mathrm{CCH}$ demonstrated higher proteolytic activity $(\mathrm{DH} \%>8.9 \%)$ than Lb. helveticus DSM1313, used here as a reference commercial strain with high proteolytic activity (Table 3). In addition, s6-HTCH with a $\mathrm{pH}>6.0$ but with the highest $\mathrm{DH} \%$ (>17.88) was also selected. The peptide profiles by RP-HPLC from s10-AVCH and s12-AVCH displayed more diverse and abundant peaks (Fig. 3B and 3C), similar to the chromatogram of AVCH (Fig. 1B). The remaining six strains which elicited higher DH\% than DSM13137 were isolated from HTCH. Whilst, s6-HTCH displayed the highest DH\%, it did not show as many peaks as s10-AVCH or s12-AVCH. This could be explained by the high final $\mathrm{pH}$ (kept above 6.4) for this strain which allowed the caseins to remain soluble which resulted in more extensive hydrolysis as shown by the peptide profile between Rt 40 and 50 min (Fig. 3A) and the production of very small peptides or FAA that would have eluted with the solvent and/or were at concentrations below the detection limits.

\subsection{Bioactivity assays in fermented milk by selected hydrolytic strains}



conditions were chosen for ACEi and antioxidant activity (AO). The inhibitory efficiency ratio (IER) is the quotient of ACEi\% divided by the TP concentration providing a better approach to the potency of inhibition than just reporting ACEi\%. The IER of DSM13137 increased over time and it was the highest of all the fermented milk fractions (Table 4), followed by s10 and s12 which were not significantly different $(\mathrm{P}<0.01)$ with IER $\approx 9$. Interestingly, s6 showed the lowest activity among the 4 strains despite showing higher DH\%. Moreover, IER value decreased after $48 \mathrm{~h}$ of fermentation suggesting further breakdown of bioactive peptides by proteolysis into inactive AA.

LAB may also generate antioxidant peptides during fermentation (Virtanen, Pihlanto, Akkanen, \& Korhonen, 2007). In this study, the antioxidant activity of the fermented samples was evaluated by both FRAP (Fig. 4A) and the ABTS methods (Fig. 4B). Both methods showed the highest AO for DSM13137 closely followed by the three strains assessed. Also, there was an increase of AO fermentation time for all strains at 48 hours compared to 24 hours. This positive correlation of AO with degree of hydrolysis is supported by results previously reported where $\mathrm{CCH}$ showed higher antioxidant activity with time of ripening (Aguilar-Toalá, Vallejo-Cordoba, Hernández-Mendoza, \& GonzálezCórdova, 2015). The range of AO observed for ABTS scavenging, 50 to $87 \%$ (>1600 $\mu \mathrm{mol} / \mathrm{L}$ TEAC), is higher than that found on sweet whey (36\%) and $\beta$-lactoglobulin (26\%) hydrolysates obtained with protease N 'Amano' after 6 hours of hydrolysis (Welderufael, 2011). Nevertheless, it is known that caseins are more susceptible to proteolysis than whey proteins, resulting in an increased AO (Power, Jakeman, \& Fitzgerald, 2013). Moreover, Virtanen et al. (2007) reported AO as $860 \mu \mathrm{mol} / \mathrm{L}$ TEAC in fermented milk by a combination LAB, including Leuconostoc cremoris, Lactococcus lactis ATCC19435 and Lb. acidophilus ATCC4356. Soleymanzadeh et al. (2016) reported antioxidant activity of Leuconostoc lactis SM10, isolated from a traditional fermented camel milk, obtaining 1484 and $311.66 \mu \mathrm{mol} / \mathrm{L}$ TEAC after 24 hours of fermentation of camel and bovine milk, respectively using the ABTS method. Interestingly, the AO reported in this study for DSM13137 $(2138.95 \pm 20.23 \mu \mathrm{mol} / \mathrm{L}$ TEAC), followed by strain s6 (2059.06 $\pm 26.27 \mu \mathrm{mol} / \mathrm{L}$ TEAC) after 48 hours of fermentation are higher than those previously reported. Overall, the three selected isolates from $\mathrm{CCH}$ (s6-HTCH, s10- 
AVCH and s12-AVCH), as well as DSM13137, show great capability to elicit AO activity upon milk

257 fermentation.

258

259

260

261

262

263

264

265

266

267

268

269

270

271

272

273

274

275

276

277

278

279

\section{CONCLUSIONS}

In this study we reported for the first time the proteolytic activity in Chiapas cheese $(\mathrm{CCH})$, particularly from the Veracruz (AVCH) and Tabasco $(\mathrm{HTCH})$ regions. There was high proteolytic activity in both cheeses, but as supported by both the free amino acids content and the peptide profile, higher proteolytic activity was found in AVCH than in HTCH. Interestingly AVCH contained high amounts of essential amino acids as FAA and the antihypertensive GABA $(0.78 \mathrm{~g} / \mathrm{kg})$; this amount is greater than what has been found in other cheese made of cow's milk and indicates the presence of LAB with capabilities to synthesise GABA. Furthermore, the proteolytic capabilities of microbiota isolated from the $\mathrm{CCH}$ was also assessed and their proteolytic activity was found similar to the reference commercial strain DSM13137. Furthermore, two of the isolated strains showed similar ACE inhibitory activity to DSM13137, and all strains tested (s6-HTCH, s10-AVCH and s12-AVCH) showed very similar antioxidant activities to the reference strain and higher than those previously reported for fermented milk. Thus, these cheese isolates with high proteolytic activity could lead to the production of functional foods with a range of biological functionalities. Further research should aim at the identification of the selected proteolytic strains and identification of major peptides responsible for the bioactivities.

\section{ACKNOWLEDGEMENTS}

This project was partly funded by the Newton Fund programme administrated by the British Council and the Erasmus+ programme for Masters placements at the University of Reading. The authors claim no conflict of interest.

\section{REFERENCES}

Aguilar-Toalá, J. E., Vallejo-Cordoba, B., Hernández-Mendoza, A., \& González-Córdova, A. F. (2015). 
Antioxidant capacity of water soluble extracts obtained from Queso Crema de Chiapas, an Artisanal Mexican Cheese. In IFT Annual Meeting and Expo, Chicago, IL. (pp. 072-04). Chicago IL: Technologists, Institute of Food.

Benzie, I. F. F., \& Strain, J. J. (1996). The Ferric Reducing Ability of Plasma (FRAP) as a Measure of “Antioxidant Power": The FRAP Assay. Analytical Biochemistry, 239(1), 70-76. https://doi.org/10.1006/abio.1996.0292

Bishop, D. K., \& Hinrichs, D. J. (1987). Adoptive transfer of immunity to Listeria monocytogenes. The influence of in vitro stimulation on lymphocyte subset requirements. Journal of Immunology (Baltimore, Md. : 1950), 139(6), 2005-2009. Retrieved from http://www.ncbi.nlm.nih.gov/pubmed/3114382

Diana, M., Rafecas, M., Arco, C., \& Quílez, J. (2014). Free amino acid profile of Spanish artisanal cheeses: Importance of gamma-aminobutyric acid (GABA) and ornithine content. Journal of Food Composition and Analysis, 35(2), 94-100. https://doi.org/10.1016/j.jfca.2014.06.007

Elmore, J. S., Koutsidis, G., Dodson, A. T., Mottram, D. S., \& Wedzicha, B. L. (2005). Measurement of Acrylamide and Its Precursors in Potato, Wheat, and Rye Model Systems. Journal of Agricultural and Food Chemistry, 53(4), 1286-1293. https://doi.org/10.1021/jf048557b

González-Córdova, A. F., Yescas, C., Ortiz-Estrada, Á. M., De la Rosa-Alcaraz, M. de los Á., Hernández-Mendoza, A., \& Vallejo-Cordoba, B. (2016). Invited review: Artisanal Mexican cheeses. Journal of Dairy Science, 99(5), 3250-3262. https://doi.org/10.3168/jds.2015-10103

Gonzalez-Gonzalez, C., Gibson, T., \& Jauregi, P. (2013). Novel probiotic-fermented milk with angiotensin I-converting enzyme inhibitory peptides produced by Bifidobacterium bifidum MF 20/5. International Journal of Food Microbiology, 167(2), 131-137. https://doi.org/10.1016/j.ijfoodmicro.2013.09.002

Gonzalez-Gonzalez, C. R., Tuohy, K. M., \& Jauregi, P. (2011). Production of angiotensin-I-converting enzyme (ACE) inhibitory activity in milk fermented with probiotic strains: Effects of calcium, pH and peptides on the ACE-inhibitory activity. International Dairy Journal, 21(9), 615-622. https://doi.org/10.1016/j.idairyj.2011.04.001

Guo, Y., \& Jauregi, P. (2018). Protective effect of $\beta$-lactoglobulin against heat induced loss of 
antioxidant activity of resveratrol. Food Chemistry.

Gupta, A., Mann, B., Kumar, R., \& Sangwan, R. B. (2009). Antioxidant activity of Cheddar cheeses at different stages of ripening. International Journal of Dairy Technology, 62(3), 339-347. https://doi.org/10.1111/j.1471-0307.2009.00509.x

Gupta, A., Mann, B., Kumar, R., \& Sangwan, R. B. (2013). ACE-Inhibitory Activity of Cheddar Cheeses Made with Adjunct Cultures at Different Stages of Ripening. Advances in Dairy Research, 01(01), 1-6. https://doi.org/10.4172/2329-888x.1000102

Henda, Y. Ben, Labidi, A., Arnaudin, I., Bridiau, N., Delatouche, R., Maugard, T., ... BordenaveJuchereau, S. (2013). Measuring angiotensin-I converting enzyme inhibitory activity by micro plate assays: Comparison using marine cryptides and tentative threshold determinations with captopril and losartan. Journal of Agricultural and Food Chemistry, 61(45), 10685-10690. https://doi.org/10.1021/jf403004e

Inoue, K., Shirai, T., Ochiai, H., Kasao, M., Hayakawa, K., Kimura, M., \& Sansawa, H. (2003). Bloodpressure-lowering effect of a novel fermented milk containing gamma-aminobutyric acid (GABA) in mild hypertensives. European Journal of Clinical Nutrition, 57(3), 490-495. https://doi.org/10.1038/sj.ejcn.1601555

King, N. (1948). A modification of the Voges-Proskauer test for rapid colorimetric determination of acetylmethylcarbinol plus diacetyl in the butter cultures. Dairy Industry, 13(9), 860-861.

Lacroix, N., St-Gelais, D., Champagne, C. P., \& Vuillemard, J. C. (2013). Gamma-aminobutyric acidproducing abilities of lactococcal strains isolated from old-style cheese starters. Dairy Science and Technology. https://doi.org/10.1007/s13594-013-0127-4

Mata, M. T., Baquero, F., \& Pérez-Díaz, J. C. (2000). A multidrug efflux transporter in Listeria monocytogenes. FEMS Microbiology Letters, 187(2), 185-188. https://doi.org/10.1016/S03781097(00)00199-3

Melgar-Lalanne, G., Rivera-Espinoza, Y., Reyes Méndez, A. I., \& Hernández-Sánchez, H. (2013). In Vitro Evaluation of the Probiotic Potential of Halotolerant Lactobacilli Isolated from a Ripened Tropical Mexican Cheese. Probiotics and Antimicrobial Proteins, 5(4), 239-251. 
Morales, F., Morales, J. I., Hernández, C. H., \& Hernández-Sánchez, H. (2011). Isolation and partial characterization of halotolerant lactic acid bacteria from two mexican cheeses. Applied Biochemistry and Biotechnology, 164(6), 889-905. https://doi.org/10.1007/s12010-011-9182-6

Nejati, F., Rizzello, C. G., Di Cagno, R., Sheikh-Zeinoddin, M., Diviccaro, A., Minervini, F., \& Gobbetti, M. (2013). Manufacture of a functional fermented milk enriched of Angiotensin-I Converting Enzyme (ACE)-inhibitory peptides and $\gamma$-amino butyric acid (GABA). LWT - Food Science and Technology, 51(1), 183-189. https://doi.org/10.1016/j.lwt.2012.09.017

Nielsen, P. M., Petersen, D., \& Dambmann, C. (2001). Improved method for determining food protein degree of hydrolysis. Journal of Food Science, 66(5), 642-646. https://doi.org/10.1111/j.13652621.2001.tb04614.x

Nomura, M., Kimoto, H., Someya, Y., Furukawa, S., \& Suzuki, I. (1998). Production of gammaaminobutyric acid by cheese starters during cheese ripening. Journal of Dairy Science, 81(6), 1486-1491. https://doi.org/10.3168/jds.S0022-0302(98)75714-5

Okamoto, A., Hanagata, H., Matsumoto, E., Kawamura, Y., Koizumi, Y., \& Yanagida, F. (1995). Angiotensin I Converting Enzyme Inhibitory Activities of Various Fermented Foods. Bioscience, Biotechnology and Biochemistry, 59(6), 1147-1149. https://doi.org/10.1271/bbb.59.1147

Ong, L., Henriksson, A., \& Shah, N. P. (2007). Angiotensin converting enzyme-inhibitory activity in Cheddar cheeses made with the addition of probiotic Lactobacillus casei sp. Le Lait. https://doi.org/10.1051/lait:2007004

Power, O., Jakeman, P., \& Fitzgerald, R. J. (2013). Antioxidative peptides: Enzymatic production, in vitro and in vivo antioxidant activity and potential applications of milk-derived antioxidative peptides. Amino Acids. https://doi.org/10.1007/s00726-012-1393-9

Qureshi, T. M., Vegarud, G. E., Abrahamsen, R. K., \& Skeie, S. (2012). Characterization of the Norwegian autochthonous cheese Gamalost and its angiotensin I-converting enzyme (ACE) inhibitory activity during ripening. Dairy Science and Technology, 92(6), 613-625. https://doi.org/10.1007/s13594-012-0078-1

R-Core-Team. (2017). R: A Language and Environment for Statistical Computing. Vienna, Austria: R 
Santiago-López, L., González-Córdova, A. F., Hernández-Mendoza, A., Aguilar-Toalá, J. E., Liceaga,

367

368

369 A. M., \& Vallejo-Cordoba, B. (2018). Invited review: Bioactive compounds produced during cheese ripening and health effects associated with aged cheese consumption. Journal of Dairy Science, 101(5), 3742-3757. https://doi.org/10.3168/jds.2017-13465

Seppo, L., Jauhiainen, T., Poussa, T., \& Korpela, R. (2003). A fermented milk high in bioactive peptides has a blood pressure-lowering effect in hypertensive subjects. The American Journal of Clinical Nutrition, 77(2), 326-330. Retrieved from http://www.ncbi.nlm.nih.gov/pubmed/12540390

Soleymanzadeh, N., Mirdamadi, S., \& Kianirad, M. (2016). Antioxidant activity of camel and bovine milk fermented by lactic acid bacteria isolated from traditional fermented camel milk (Chal). Dairy Science and Technology, 96(4), 443-457. https://doi.org/10.1007/s13594-016-0278-1

Virtanen, T., Pihlanto, A., Akkanen, S., \& Korhonen, H. (2007). Development of antioxidant activity in milk whey during fermentation with lactic acid bacteria. Journal of Applied Microbiology, 102(1), 106-115. https://doi.org/10.1111/j.1365-2672.2006.03072.x

Welderufael, F. T. (2011). Development of an integrative process for the production of angiotensin converting enzyme inhibitory peptides from whey using proteolytic mixtures. $\mathrm{PhD}$ Thesis. University of Reading. 
Table 1. $\mathrm{IC}_{50}$ values for $\mathrm{ACE}$ inhibitory activity, protein content and $\mathrm{pH}$ for Chiapas cheese samples from Veracruz $(\mathrm{AVCH})$ and Tabasco $(\mathrm{HTCH})(\mathrm{n}=2, \pm$ s.e. $)$.

\begin{tabular}{lcc}
\hline Activity & AVCH & HTCH \\
\hline ACE inhibition $\left(\mathrm{IC}_{50} \mathrm{mg} / \mathrm{mL}\right)$ & $2.75 \pm 0.50^{\mathrm{a}}$ & $1.75 \pm 0.49^{\mathrm{a}}$ \\
Total protein $(\mathrm{g} / 100 \mathrm{~g})$ & $26.95 \pm 3.44^{\mathrm{b}}$ & $23.72 \pm 2.88^{\mathrm{b}}$ \\
$\mathrm{pH}$ & $3.90 \pm 0.06^{\mathrm{c}}$ & $3.95 \pm 0.09^{\mathrm{c}}$ \\
\hline
\end{tabular}

a,b,c No statistical difference between the means with the same letter; $\alpha=0.05$. 
Table 2. Levels of free derivatised amino acids in raw milk and Chiapas cheese samples from Veracruz $(\mathrm{AVCH})$ and Tabasco $(\mathrm{HTCH})$.

\begin{tabular}{lccc}
\hline Amino acid & $\begin{array}{c}\text { Raw milk } \\
\text { g/kg }\end{array}$ & $\begin{array}{c}\text { AVCH } \\
\text { g/kg }\end{array}$ & $\begin{array}{c}\text { HTCH } \\
\mathbf{g} / \mathbf{k g}\end{array}$ \\
\hline Alanine & 0.005 & 0.283 & 0.072 \\
a-aminobutyric acid & 0.001 & 0.022 & $\mathrm{ND}$ \\
Asparagine & $\mathrm{Tr}^{1}$ & 0.135 & 0.009 \\
Aspartic acid & 0.010 & 0.148 & 0.010 \\
$\boldsymbol{\gamma}$-aminobutyric acid & $\mathbf{N D}^{\mathbf{2}}$ & $\mathbf{0 . 7 8 4}$ & $\mathbf{0 . 1 6 0}$ \\
Glutamic acid & 0.059 & 0.076 & 0.009 \\
Glutamine & $\mathrm{ND}$ & 0.038 & $\mathrm{ND}$ \\
Glycine & 0.008 & 0.095 & 0.020 \\
Histidine & $\mathrm{ND}$ & 0.003 & $\mathrm{ND}$ \\
Isoleucine & 0.001 & $\mathrm{ND}$ & $\mathrm{Tr}$ \\
Leucine & 0.001 & 0.757 & 0.085 \\
Lysine & 0.002 & 0.464 & 0.031 \\
Methionine & $\mathrm{Tr}$ & 0.157 & $\mathrm{ND}$ \\
Ornithine & 0.001 & 0.179 & $\mathrm{ND}$ \\
Phenylalanine & 0.001 & 0.223 & 0.032 \\
Proline & 0.003 & 0.070 & 0.064 \\
Serine & $\mathrm{Tr}$ & 0.147 & $\mathrm{ND}$ \\
Threonine & 0.001 & 0.089 & $\mathrm{ND}$ \\
Tyrosine & 0.001 & 0.016 & 0.019 \\
Tryptophan & 0.001 & 0.009 & $\mathrm{ND}$ \\
Valine & 0.004 & 0.204 & 0.028 \\
\hline
\end{tabular}

${ }^{2} \mathrm{Tr}$, traces

${ }^{1} \mathrm{ND}$, None detected. 
Table 3. Screening of lactic acid bacteria isolated from Chiapas cheeses from Veracruz (AVCH) and Tabasco (HTCH) for their catalase activity, diacetyl production and $\mathrm{pH}$ of fermented reconstituted skim milk (RSM) to determine those with desirable characteristics (DC). ${ }^{\dagger}$

\begin{tabular}{|c|c|c|c|c|c|c|c|}
\hline ID & Origin & Atmosphere & Catalase & Diacetyl & pH & DC & DH(\%) \\
\hline s1 & $\mathrm{HTCH}$ & Aerobic & - & - & 6.28 & & ND \\
\hline s2 & $\mathrm{HTCH}$ & Aerobic & - & + & 5.29 & & 8.03 \\
\hline s3 & $\mathrm{HTCH}$ & Aerobic & - & - & 5.50 & & ND \\
\hline s4 & $\mathrm{HTCH}$ & Aerobic & - & - & 6.10 & & ND \\
\hline s5 & $\mathrm{HTCH}$ & Aerobic & + & + & 5.71 & & 11.11 \\
\hline s6 & $\mathrm{HTCH}$ & Aerobic & - & + & 6.46 & $*$ & 17.88 \\
\hline s7 & $\mathrm{AVCH}$ & Aerobic & + & - & 6.65 & & ND \\
\hline s8 & $\mathrm{AVCH}$ & Aerobic & + & - & 6.66 & & ND \\
\hline s9 & $\mathrm{AVCH}$ & Aerobic & - & - & 6.58 & & ND \\
\hline s10 & $\mathrm{AVCH}$ & Aerobic & - & + & 5.31 & $*$ & 13.41 \\
\hline s11 & $\mathrm{AVCH}$ & Aerobic & + & - & 6.59 & & ND \\
\hline s12 & $\mathrm{AVCH}$ & Aerobic & - & + & 5.54 & $*$ & 11.00 \\
\hline s13 & $\mathrm{AVCH}$ & Aerobic & + & - & 6.70 & & ND \\
\hline s15 & $\mathrm{AVCH}$ & Aerobic & - & - & 6.30 & & ND \\
\hline s16 & $\mathrm{AVCH}$ & Aerobic & - & - & 6.74 & & ND \\
\hline s17 & $\mathrm{AVCH}$ & Aerobic & - & - & 6.73 & & ND \\
\hline s18 & $\mathrm{AVCH}$ & Aerobic & - & - & 6.65 & & ND \\
\hline s19 & $\mathrm{HTCH}$ & Aerobic & - & - & 5.98 & & ND \\
\hline s21 & $\mathrm{HTCH}$ & Aerobic & + & - & 6.77 & & ND \\
\hline s22 & HTCH & Aerobic & - & - & 6.23 & & ND \\
\hline s23 & $\mathrm{HTCH}$ & Aerobic & - & - & 6.09 & & ND \\
\hline s24 & HTCH & Aerobic & - & - & 6.18 & & ND \\
\hline s 25 & $\mathrm{HTCH}$ & Aerobic & - & - & 6.10 & & ND \\
\hline s26 & $\mathrm{HTCH}$ & Aerobic & - & - & 5.88 & & ND \\
\hline s27 & $\mathrm{HTCH}$ & Aerobic & + & + & 5.49 & & 8.78 \\
\hline s28 & $\mathrm{HTCH}$ & Aerobic & - & + & 4.63 & $*$ & 11.26 \\
\hline s30 & $\mathrm{HTCH}$ & Anaerobic & & & 6.24 & & ND \\
\hline
\end{tabular}




\begin{tabular}{|c|c|c|c|c|c|c|c|}
\hline s31 & HTCH & Anaerobic & - & + & 5.28 & & 0.00 \\
\hline s32 & $\mathrm{HTCH}$ & Anaerobic & - & + & 6.62 & & 1.79 \\
\hline s33 & HTCH & Anaerobic & - & + & 5.11 & & 1.16 \\
\hline s34 & $\mathrm{HTCH}$ & Anaerobic & - & - & 5.71 & & ND \\
\hline s35 & HTCH & Anaerobic & - & + & 4.80 & & 4.01 \\
\hline s36 & $\mathrm{HTCH}$ & Anaerobic & - & + & 4.92 & & 3.10 \\
\hline s37 & HTCH & Anaerobic & - & - & 6.11 & & ND \\
\hline $\mathrm{s} 38$ & $\mathrm{HTCH}$ & Anaerobic & - & - & 6.08 & & $\mathrm{ND}$ \\
\hline s39 & HTCH & Anaerobic & - & + & 5.98 & & 5.43 \\
\hline $\mathrm{s} 40$ & $\mathrm{HTCH}$ & Anaerobic & - & + & 5.60 & & 4.00 \\
\hline s41 & HTCH & Anaerobic & - & - & 5.94 & & ND \\
\hline $\mathrm{s} 42$ & HTCH & Anaerobic & - & - & 6.44 & & ND \\
\hline$s 43$ & HTCH & Anaerobic & - & + & 4.70 & * & 10.24 \\
\hline s44 & $\mathrm{HTCH}$ & Anaerobic & - & + & 4.48 & & 8.32 \\
\hline s46 & HTCH & Anaerobic & - & + & 4.83 & * & 10.62 \\
\hline s47 & $\mathrm{HTCH}$ & Anaerobic & - & - & 6.64 & & ND \\
\hline s 48 & $\mathrm{HTCH}$ & Anaerobic & - & + & 4.98 & * & 10.43 \\
\hline s49 & HTCH & Anaerobic & - & - & 4.06 & & $\mathrm{ND}$ \\
\hline $\mathrm{s} 50$ & HTCH & Anaerobic & - & + & 5.38 & & 4.88 \\
\hline s51 & $\mathrm{HTCH}$ & Anaerobic & - & + & 5.27 & & 3.63 \\
\hline s52 & HTCH & Anaerobic & - & - & 4.21 & & ND \\
\hline s53 & HTCH & Anaerobic & - & - & 4.50 & & ND \\
\hline s54 & HTCH & Anaerobic & - & - & 6.60 & & ND \\
\hline s55 & $\mathrm{AVCH}$ & Anaerobic & - & - & 5.92 & & ND \\
\hline s58 & $\mathrm{AVCH}$ & Anaerobic & - & - & 6.10 & & ND \\
\hline s59 & $\mathrm{AVCH}$ & Anaerobic & - & - & 6.80 & & ND \\
\hline s60 & $\mathrm{AVCH}$ & Anaerobic & - & - & 6.60 & & ND \\
\hline s61 & AVCH & Anaerobic & - & - & 6.80 & & ND \\
\hline s62 & $\mathrm{AVCH}$ & Anaerobic & - & - & 6.81 & & ND \\
\hline s63 & $\mathrm{AVCH}$ & Anaerobic & - & - & 6.73 & & ND \\
\hline s65 & $\mathrm{AVCH}$ & Anaerobic & - & - & 6.81 & & ND \\
\hline
\end{tabular}




$\begin{array}{lllllll}\text { s66 } & \text { AVCH } & \text { Anaerobic } & - & - & 6.26 & \text { ND } \\ \text { s67 } & \text { AVCH } & \text { Anaerobic } & - & - & 6.93 & \text { ND } \\ \text { s68 } & \text { AVCH } & \text { Anaerobic } & - & - & 6.60 & \text { ND } \\ \text { s69 } & \text { AVCH } & \text { Anaerobic } & - & - & 6.13 & \text { ND } \\ \text { s70 } & \text { AVCH } & \text { Anaerobic } & - & - & 5.91 & \text { ND } \\ \text { s71 } & \text { AVCH } & \text { Anaerobic } & - & + & 6.16 & 5.67 \\ \text { s72 } & \text { AVCH } & \text { Anaerobic } & - & - & 6.36 & \text { ND } \\ \text { s73 } & \text { AVCH } & \text { Anaerobic } & - & - & 6.69 & \text { ND } \\ \text { s74 } & \text { AVCH } & \text { Anaerobic } & - & - & 6.64 & \text { ND } \\ \text { s76 } & \text { AVCH } & \text { Anaerobic } & - & + & 5.37 & 0.0 \\ \text { s86 } & \text { AVCH } & \text { Anaerobic } & - & - & 6.14 & \text { ND }\end{array}$

\footnotetext{
${ }^{\dagger}(-)$ negative reaction; (+) positive reaction. $\mathrm{pH}$ of uninoculated RSM (control) was $6.50 \pm 0.03$. Those strains showing an equivalent fingerprint have been omitted. $\mathrm{DH}(\%)$, degree of hydrolysis of milk proteins (\%); negative control (RSM) $3.18 \%$ and positive control (Lactobacillus helveticus DSM1317) 8.84\%. The specific desirable characteristics were catalase negative, capable of diacetyl production and $\mathrm{DH} \%>8.9 \%$.
} 

2 Table 4. Inhibitory efficiency ratio (ACEi\%/[total protein $\left.\mathrm{mg} \mathrm{mL}^{-1}\right]$ ) of fermented milk whey samples of selected 3 strains (s6-HTCH, s10-AVCH \& s12-AVCH) compared to Lb. helveticus DSM13137. Results are represented by the $4 \quad$ mean $\pm \mathrm{SD}(\mathrm{n}=2)$

5

\begin{tabular}{lcccc}
\hline Time (hours) & DSM13137 & s6-HTCH & s10-AVCH & s12-AVCH \\
\hline 24 & $12.32 \pm 0.01^{\mathrm{a}, \mathrm{b}}$ & $4.61 \pm 0.49^{\mathrm{b}, \mathrm{c}}$ & $9.75 \pm 0.31^{\mathrm{b}, \mathrm{c}}$ & $9.09 \pm 0.01^{\mathrm{b}}$ \\
48 & $15.42 \pm 0.25^{\mathrm{a}, \mathrm{b}}$ & $3.74 \pm 1.21^{\mathrm{b}, \mathrm{c}}$ & $8.32 \pm 1.31^{\mathrm{b}, \mathrm{c}}$ & $9.11 \pm 0.59^{\mathrm{b}, \mathrm{c}}$
\end{tabular}

6

* Treatments with the same letter are not significantly different, Tukey HSD test: $\alpha=0.05$

7

8

9

10 

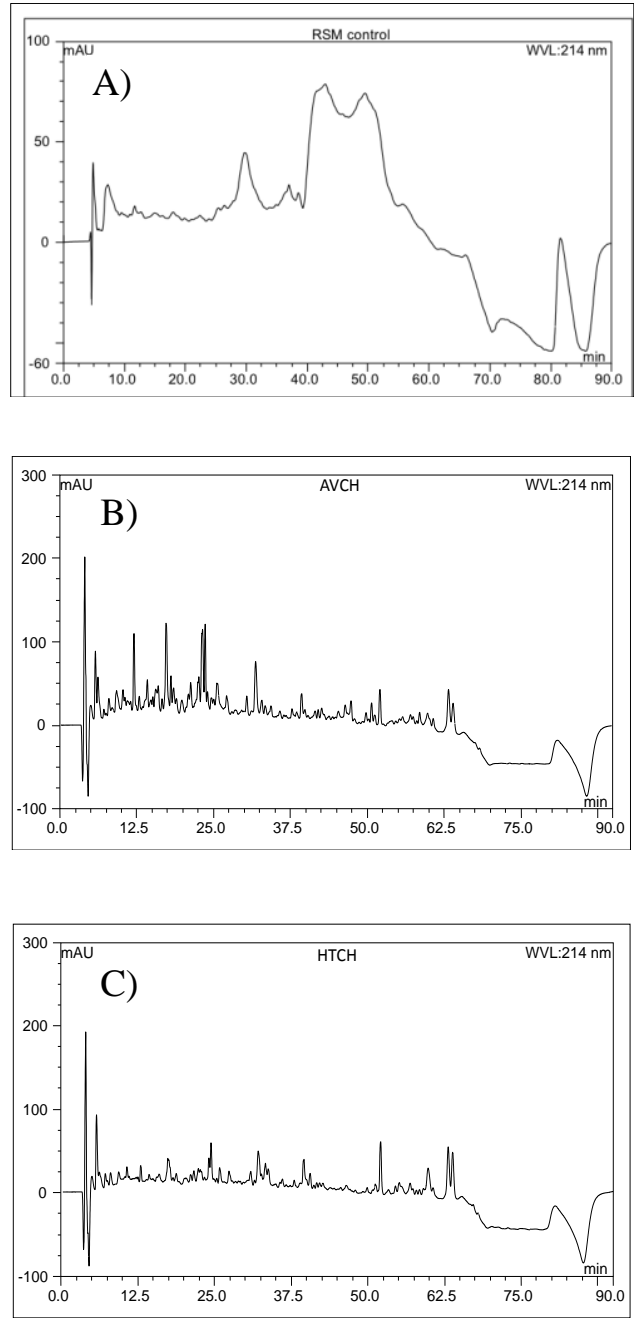

Fig. 1. RP-HPLC peptide profiles of A) reconstitute skimmed milk (RSM); B) Chiapas cheese from Veracruz $(\mathrm{AVCH})$; and $\mathrm{C})$ from Tabasco $(\mathrm{HTCH})$. 


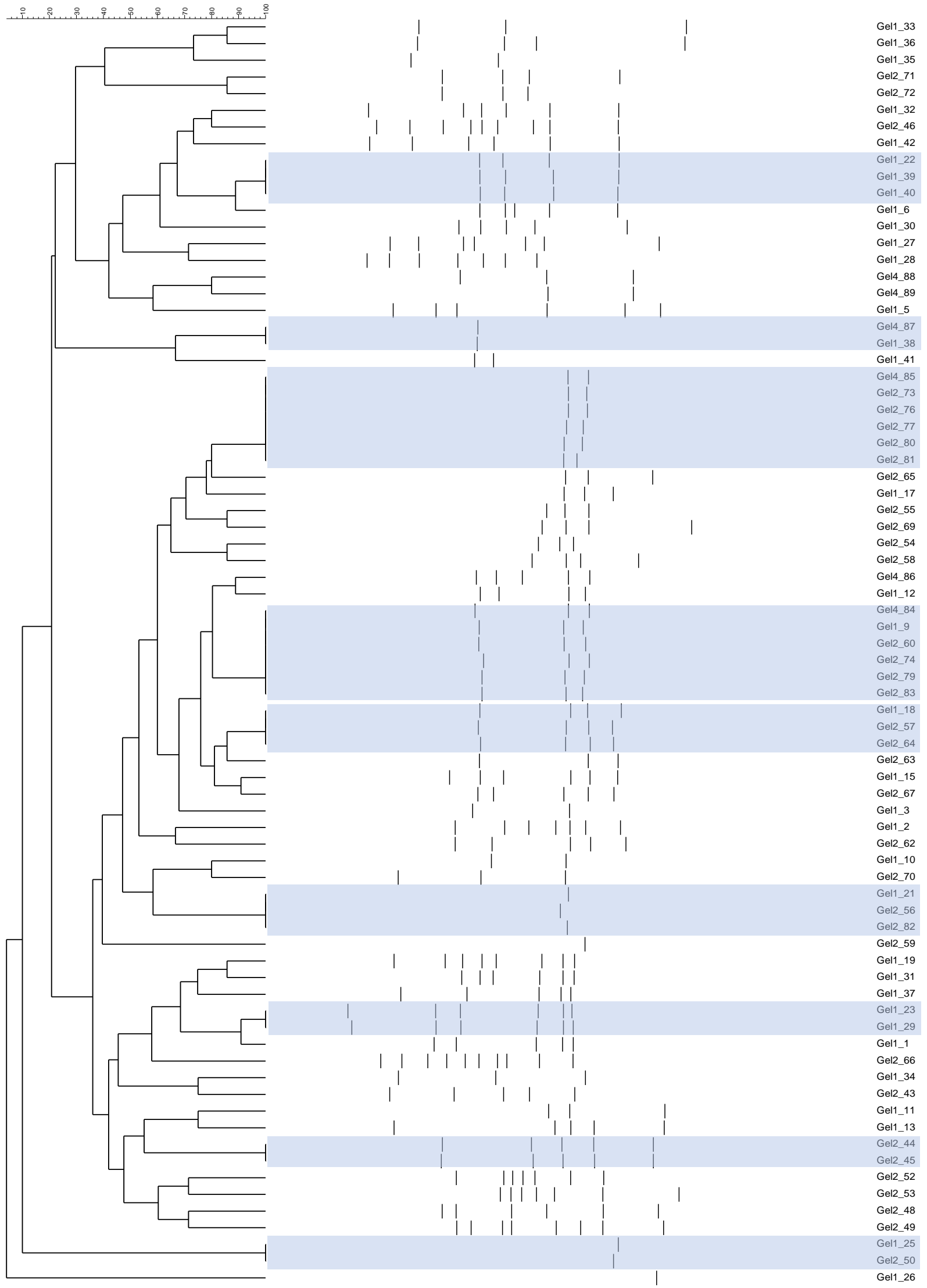

Fig. 2. Investigation of the genetic variation of lactic acid bacteria isolated from Chiapas cheeses using RAPD-PCR (OPA-09). Profiles are labelled with gel number followed by isolate number (e.g. Gel1_33, refers to isolate 33 whose RAPD-PCR product was run in Gel 1). Grey shading highlights potential replicates of the same strain (100\% similarity between RAPD-PCR profiles). 

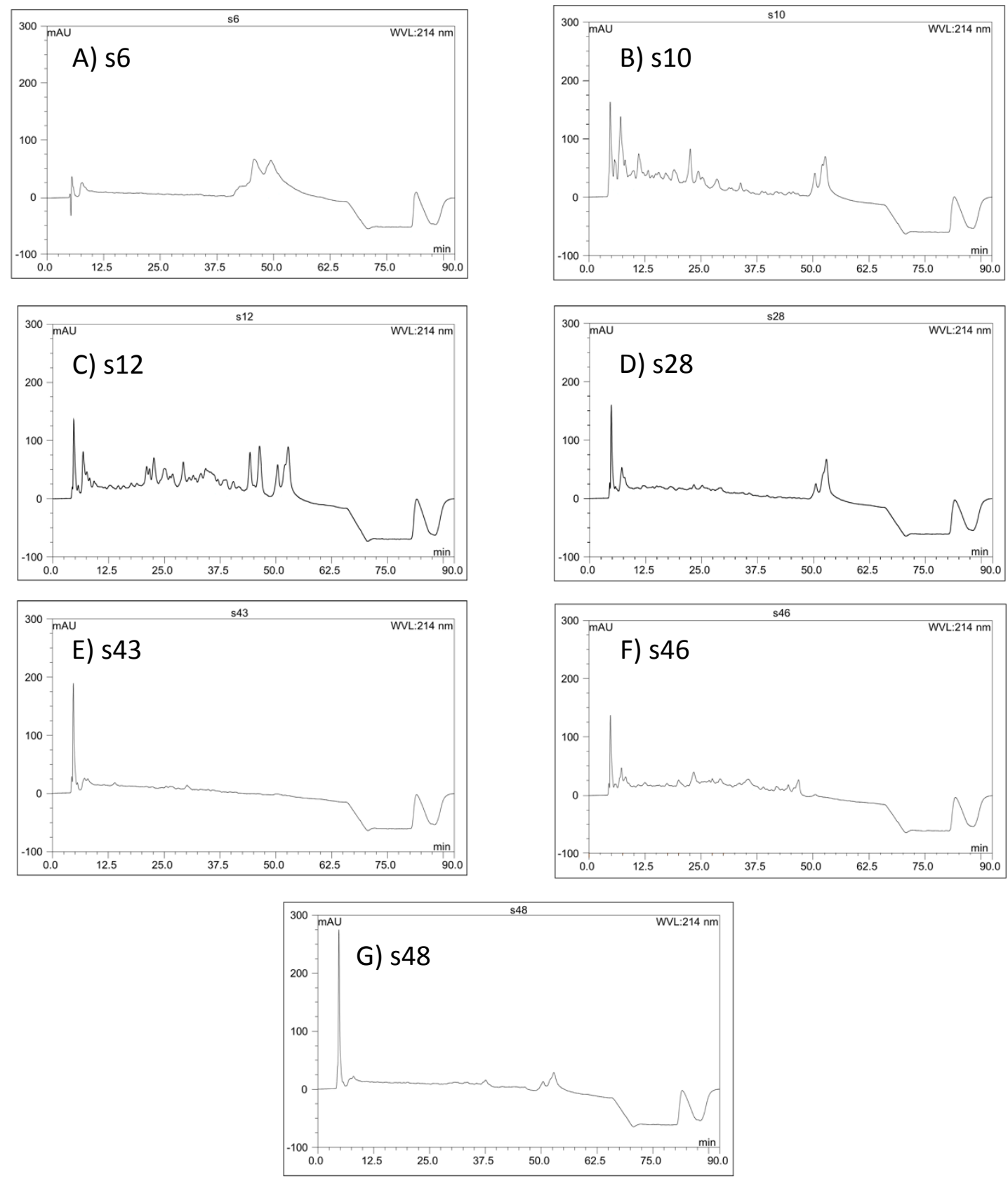

Fig. 3. Reverse phase chromatograms of peptide profiles of fermented milk whey fractions of lactic acid bacteria (s6-HTCH, s10-AVCH, s12-AVCH, s28-HTCH, s43-HTCH, s46-HTCH, and s48-HTCH) isolated from Chiapas cheese samples. 
A)

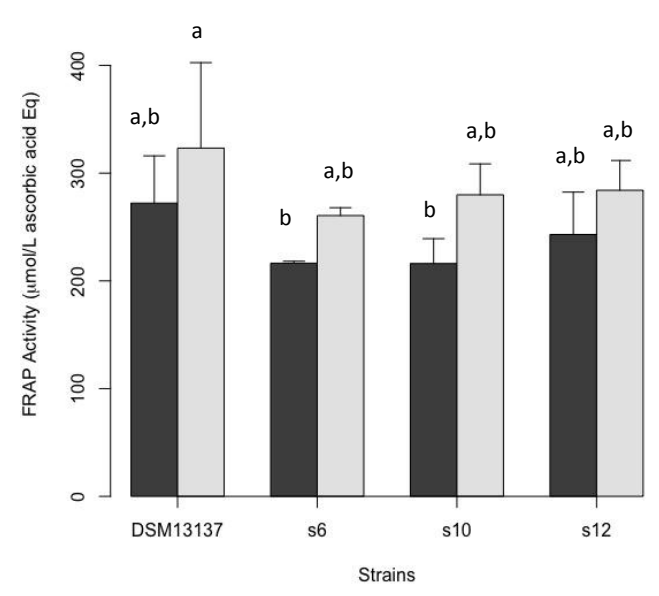

B)

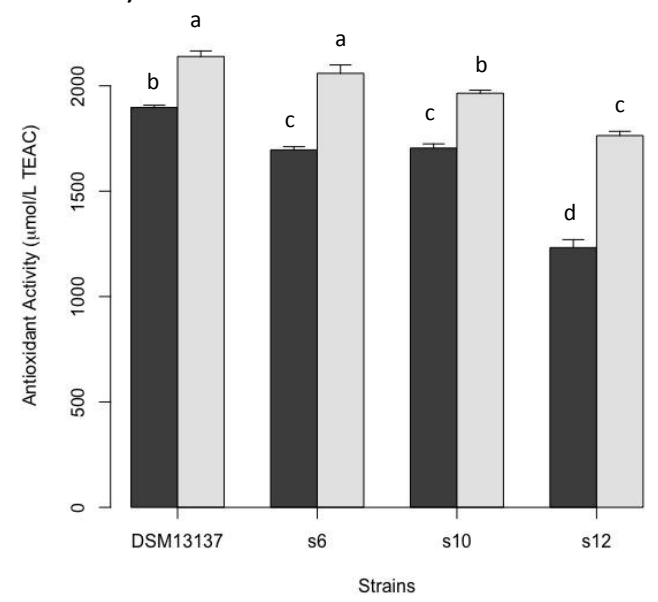

Fig. 4. Antioxidant activity of fermented milk whey fractions after 24 (dark grey) and 48 hours (light grey) fermentation by Lactobacillus helveticus DSM13137, s6-HTCH, s10-AVCH, and s12-AVCH. A) FRAP; and B) ABTS. Data are presented as means \pm SD $(n=3)$. Treatments with the same letter are not significantly different, Tukey HSD test: $\alpha=0.05$ 